\title{
A NEW INCLUSION BODY IN RHEUMATOID SYNOVIA
}

BY

\author{
T. C. HIGHTON, D. E. CAUGHEY, AND D. G. RAYNS
}

From the Rheumatism Research Laboratories, Wellcome Medical Research Institute, and the N.Z.M.R.C. Electron Microscope Unit, the Medical School, University of Otago, Dunedin, New Zealand

As part of the current research programme these laboratories are investigating the synovia of normal and abnormal human joints by light and electron microscopy. By synovia is meant the material lining joints and tendon sheaths on the interior of the fibrous capsule, including, therefore, synovial cells, loose connective tissue, blood vessels, and inflammatory cells which may be present.

Several descriptions of the fine structure of normal or near normal human synovium have been published (Barland, Novikoff, and Hamerman, 1962, and Coulter, 1962), and also of the synovium in rheumatoid arthritis (Barland, Novikoff, and Hamerman, 1964).

However, none of these has included a study of blood vessels. In view of the importance of the alterations in blood vessels seen on light micro- scopy (Kulka, Bocking, Ropes and Bauer, 1955), it was thought worth while to pay these particular attention during this ultrastructural study, and it is the purpose of this paper to draw attention to some endothelial inclusion bodies occurring within, or immediately adjacent to, small synovial blood vessels in rheumatoid arthritis which we think sufficiently interesting to merit further investigation. A brief preliminary report has already been published (Highton, Caughey, and Rayns, 1965)

\section{Material and Methods}

The clinical particulars of nine subjects studied are shown in the Table.

Samples of normal synovium were obtained by injecting veronal acetate-buffered 1 per cent. osmium tetroxide with sucrose (Caulfield, 1957) into the knee joint of the cadaver of a 39-year-old man immediately

TABLE

CLINICAL DETAILS OF FIVE PATIENTS AND FOUR CONTROLS

\begin{tabular}{|c|c|c|c|c|c|c|c|c|c|}
\hline Series & No. & Sex & $\begin{array}{c}\text { Age } \\
\text { (yrs) }\end{array}$ & $\begin{array}{c}\text { Joint } \\
\text { Disorder }\end{array}$ & $\begin{array}{l}\text { Duration } \\
\text { of Joint } \\
\text { Disorder } \\
\quad \text { (yrs) }\end{array}$ & $\begin{array}{c}\text { Titre of } \\
\text { Sensitized } \\
\text { Sheep Cell } \\
\text { Agglutination } \\
\text { Test }\end{array}$ & $\begin{array}{l}\text { Erosion } \\
\text { of Joint } \\
\text { Surfaces } \\
\text { on } x \text { ray }\end{array}$ & Nodules & Comments \\
\hline \multirow{5}{*}{$\begin{array}{l}\text { Patients } \\
\text { with } \\
\text { Rheumatoid } \\
\text { Arthritis }\end{array}$} & 1 & $\mathbf{F}$ & 37 & $\begin{array}{c}\text { Rheumatoid } \\
\text { arthritis }\end{array}$ & 3 & $1 / 128$ & + & - & $\begin{array}{l}\text { Synovectomy of right 3rd MCP } \\
\text { joint and of flexor and tendon } \\
\text { sheath of this finger. } \\
\text { Disorder present here for one } \\
\text { year. }\end{array}$ \\
\hline & 2 & $\mathbf{F}$ & 59 & $\begin{array}{c}\text { Rheumatoid } \\
\text { arthritis }\end{array}$ & 4 & $1 / 512 \rightarrow 1 / 1280$ & + & 一 & Synovectomy of knee. \\
\hline & 3 & $\mathbf{F}$ & 35 & $\begin{array}{c}\text { Rheumatoid } \\
\text { arthritis }\end{array}$ & 8 & $1 / 16$ & + & - & $\begin{array}{l}\text { Excision of left synovial sheaths } \\
\text { flexor and extensor tendons of } \\
\text { wrist. }\end{array}$ \\
\hline & 4 & $\mathbf{F}$ & 68 & $\begin{array}{c}\text { Rheumatoid } \\
\text { arthritis }\end{array}$ & 4 & $1 / 8192$ & + & + & $\begin{array}{l}\text { Excision of femoral head. } \\
\text { Insertion Austin Moore pros- } \\
\text { thesis. }\end{array}$ \\
\hline & 5 & $\mathbf{F}$ & 40 & $\begin{array}{c}\text { Rheumatoid } \\
\text { arthritis }\end{array}$ & 13 & $1 / 256$ & + & - & $\begin{array}{l}\text { Synovectomy of right } 2 \text { nd and } \\
\text { 3rd MCP joints. }\end{array}$ \\
\hline \multirow{4}{*}{ Controls } & 6 & $\mathbf{M}$ & 27 & $\begin{array}{l}\text { Torn medial } \\
\text { meniscus }\end{array}$ & $5 / 12$ & - & - & 一 & Medial menisectomy. \\
\hline & 7 & $\mathbf{M}$ & 39 & $\begin{array}{l}\text { Had acute } \\
\text { rheumatic } \\
\text { fever } 16 \\
\text { years ago }\end{array}$ & - & 一 & - & 一 & $\begin{array}{l}\text { Had rheumatic heart disease } \\
\text { Sudden death from pulmonary } \\
\text { embolus. }\end{array}$ \\
\hline & 8 & $\mathbf{M}$ & 22 & $\begin{array}{l}\text { Torn medial } \\
\text { meniscus }\end{array}$ & $1 \frac{1}{2}$ & - & - & - & Medial menisectomy \\
\hline & 9 & $\mathbf{M}$ & 25 & $\begin{array}{c}\text { Torn medial } \\
\text { meniscus }\end{array}$ & $4 / 12$ & - & - & - & $\begin{array}{l}\text { Medial Menisectomy } \\
\text { Surgeon noted "small amount of } \\
\text { synovial reaction on outer side } \\
\text { medial condyle" }\end{array}$ \\
\hline
\end{tabular}


after death (Case 7), and the fixed tissues were then excised within half an hour. The subject had died from causes which did not directly affect his joints (pulmonary embolism and rheumatic heart disease-the last attack of rheumatic fever having occurred 16 years previously).

The samples from five women with rheumatoid arthritis (Cases 1-5) and from three men with tears of the medial meniscus (Cases 6, 8, and 9) were obtained at operation, using standard orthopaedic procedures including the use of a tourniquet. The samples were placed immediately after removal either in sucrose formalin (Sabatini, Bensch, and Barrnett, 1963) or in the osmium tetroxide fixative. In Case 3 the samples were dehydrated in alcohol and embedded in Durcupan. All the others were dehydrated with graded acetones and embedded in Vestopal W.

Thin sections were cut with a Porter-Blum ultramicrotome, "stained" with 1 per cent. uranyl acetate in 50 per cent. ethanol, and examined with a Philips EM 100 B electron microscope.

\section{Results}

The normal synovial "membrane" comprises a loose aggregation of cells overlying tissue in which collagen fibres may be seen with fibrocytes and blood vessels; see for example Fig. 1 (opposite), which is a vertical section of the membrane from Case 6. Note the blood vessel V. The normal appearances of a small blood vessel are seen in Fig. 2 (opposite), taken from the synovium of Case 7. The appearances of a blood vessel from a patient with rheumatoid arthritis (Case 2) are shown in Fig. 3 (opposite); when this is compared with Fig. 2, it may be seen that ill-defined fibrillar material surrounds the vessel and that the endothelial cells have become structurally altered with the production of electron dense areas (arrow). The endothelial cells lining normal vessels (Fig. 4, overleaf-Case 7) have pinocytotic vesicles along the plasma membrane (arrows), mitochondria, and an irregularly-shaped nucleus.

On examining the vessels of rheumatoid synovia we found rod-shaped inclusion bodies in the pericytes in Case 2. Fig. 5 (overleaf) shows such a cell, containing these objects $(R)$. The mitochondria appear normal, but there are several membranelimited vesicles and the endoplasmic reticulum appears swollen.

In Case 3 the endothelial cells were found to contain several rod-shaped bodies ( $R$ in Fig. 6, overleaf) where such bodies are seen in various planes of section. Fine fibrillar material and numerous small vesicles are also seen in the cell. In some of the endothelial cells the rod-shaped bodies were present in greater numbers (Fig. 7, overleaf); in this figure details of the sub-structure of these objects are visible, for example a longitudinal orientation of material is seen within these structures suggesting a wall-like investment. This is more clearly apparent in the inset (arrows). The dimensions of the rods are length 0.25 to $1.0 \mu$, breadth 0.04 to $0.1 \mu$. InP. cases in which measurements were possible, the apparent wall measured 150 to $220 \AA$ in thickness $\overrightarrow{\vec{F}}$

In the same synovium some rods showed a sug gestion of a transverse orientation of substructure with a periodicity of approximately $80 \AA . *$

Similar, but less definite, rod-shaped bodies in endothelial cells were seen in material from Case 4 은 Thus these bodies were found in two, and possibly three, out of the five rheumatoid arthritics studied.

\section{Discussion}

In recent years there has been renewed interest in the possibility that rheumatoid arthritis may be due to an infective agent (Leader, Brit. med. J., 1965 v Sharp, 1964).

With this current atmosphere of thought, it is $\vec{x}$ tempting to speculate that these intracellular $\operatorname{rod}_{0}^{0}$ shaped inclusion bodies found in endothelial cells and pericytes of synovial blood vessels may be phases of an infective agent. It is of course realizedu that they may be reactions on the part of the intra $\frac{\rho}{5}$ cellular structures to the disease. They areapparently not enclosed in vacuoles (which suggegtso that they have not been ingested). Their distriteition in the cytoplasm appears to be a random ome When routine cultures of the synovial membrans and synovial fluid for bacteria and tubercle bacillp were prepared, no growth was obtained in any of the samples, nor was any growth obtained in speciaß cultures for P.P.L.O. However, in Case 3, cytotoxic $\overrightarrow{5}$ effects are being observed in tissue culture (Middle- 3 ton, 1965). It is perhaps a pertinent fact that Andersen (1964) has recently described a close. ontogenetic relationship between synovial cells and cells of synovial blood vessels. Kurtz, Davis, and? Ruffin (1962), Kent, Layton, Clifton, and Schedf

* Footnote added in proof: Our present work indicates that the statement in this paragraph may have to be modified.

Fig. 1.-Vertical section of near-normal synovium. $\times 3,400$ AB Cells comprising synovium

CF Collagen with fibroblasts

J Joint cavity

V Blood vessel

Fig. 2.-Transverse section normal synovial blood vessel. $\times 7,000 \mathrm{~N}$ C Collagen

E Endothelial Cell

L Lumen

Fig. 3.-Transverse section, rheumatoid synovial blood vessel $\times 6,5000$ E Endothelial cell

L Lumen

P Pericyte

R Erythrocyte

$\rightarrow$ Electron dense regions 

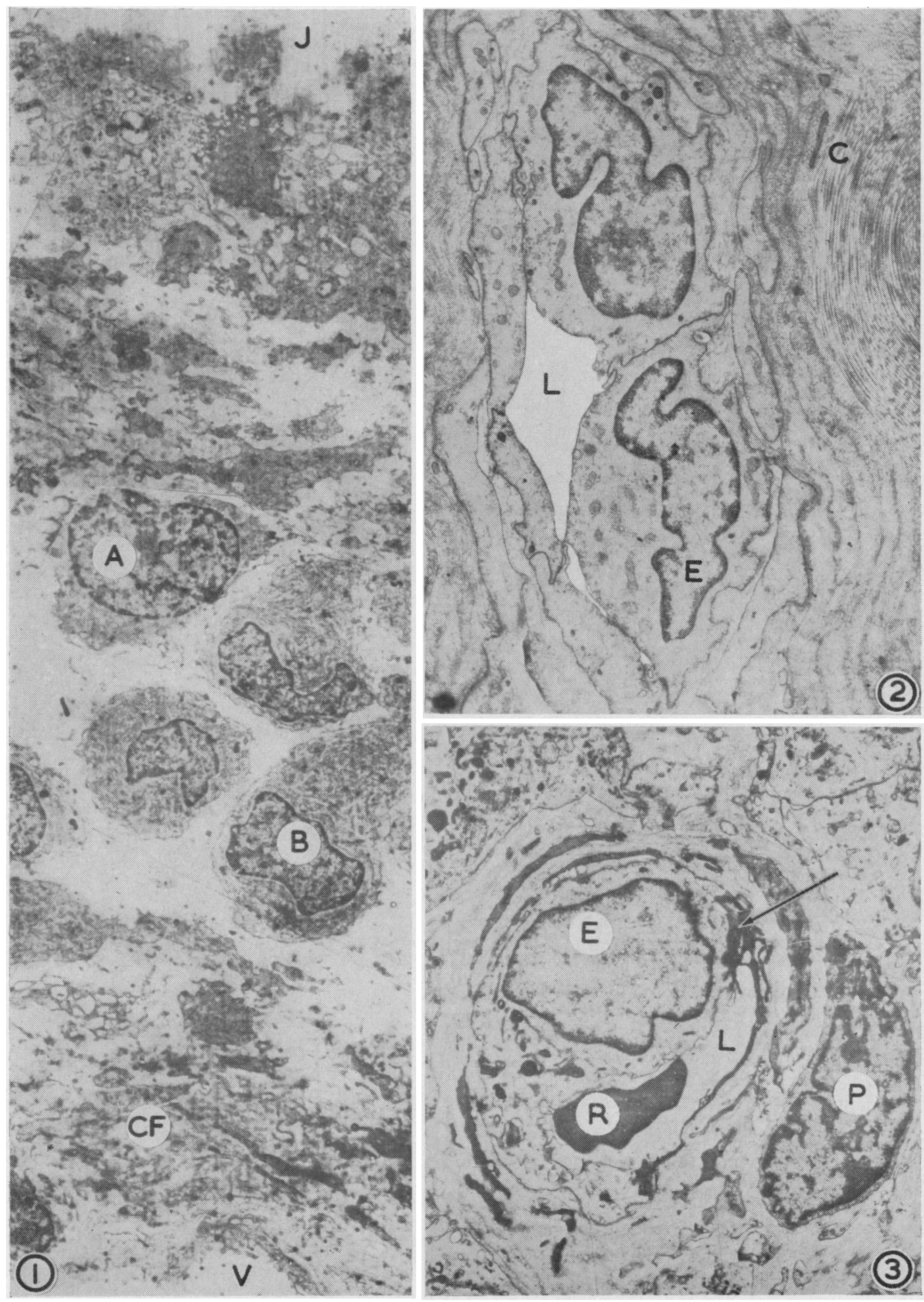


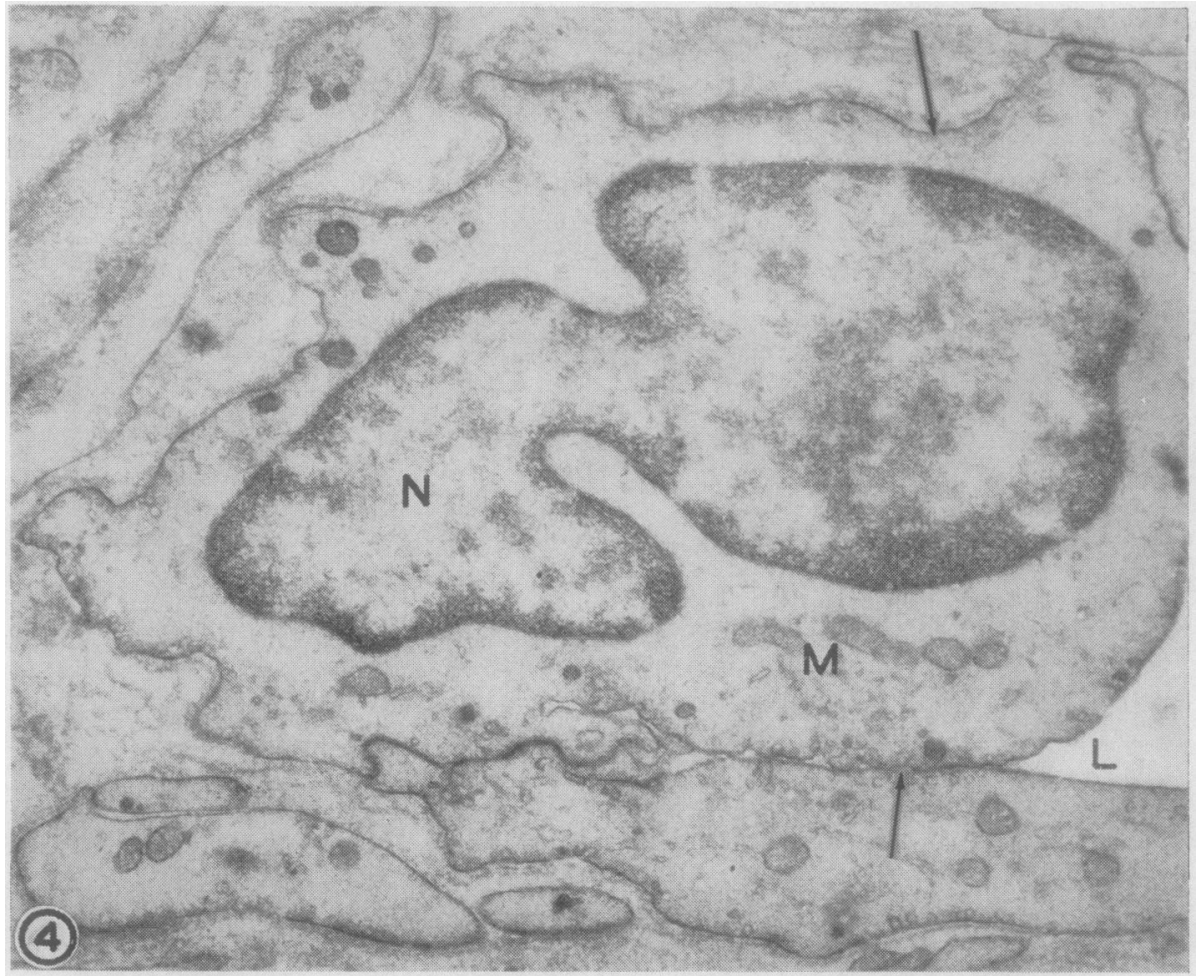

Fig. 4.-Endothelial coll normal synovial blood vessel,

L $\quad$ Lumen $\times 20,000$.

N Nucleus

Pinocytotic vesicle
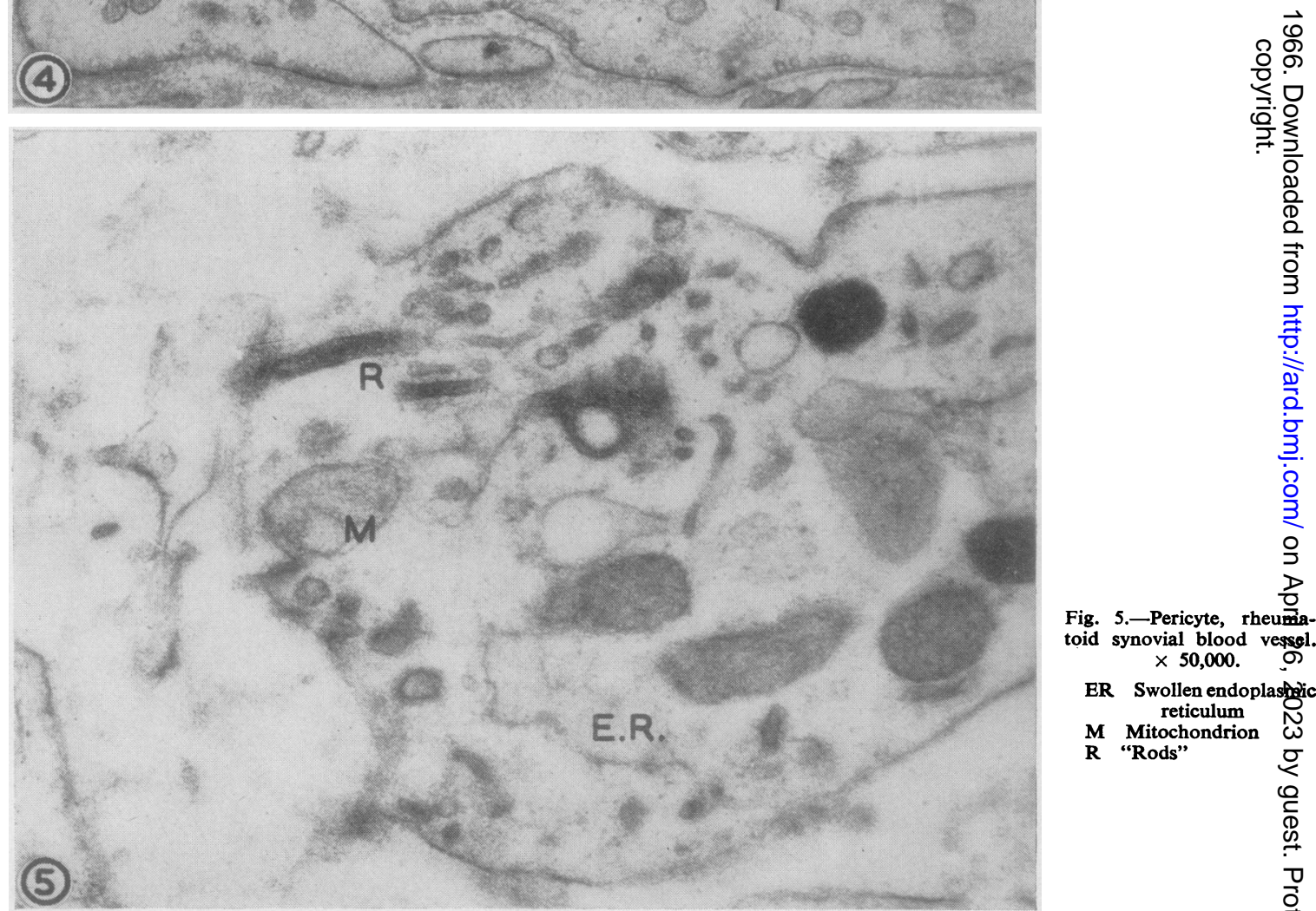

Fig, 5.-Pericyte, rheumatoid synovial blood vess. $\times 50,000$.

ER Swollen endoplastagic reticulum

M Mitochondrion R "Rods" 


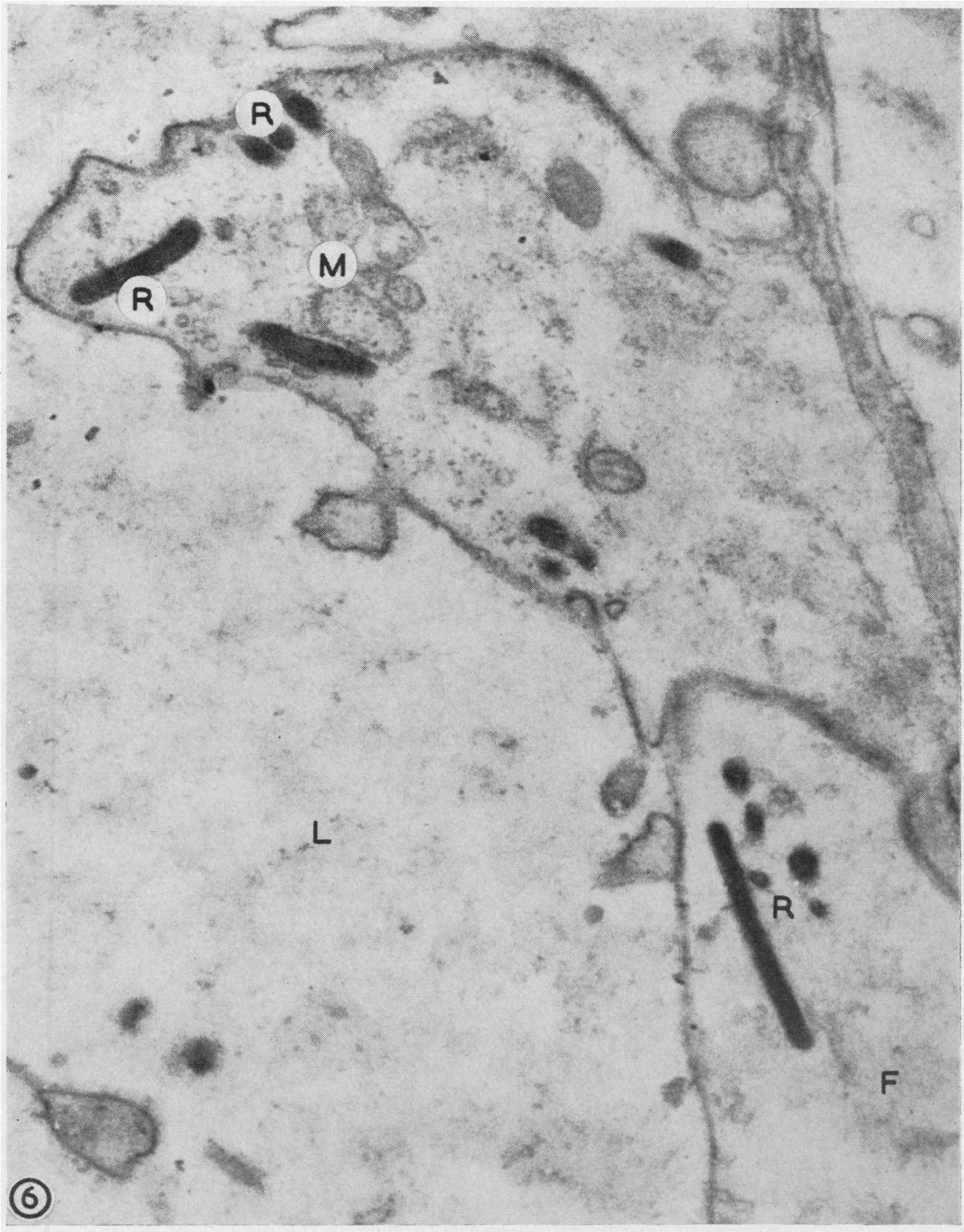

Fig. 6. -Endothelial cells, rheumatoid synovial blood vessel. $\times 37,000$.

F Fibrillar material

L Lumen

M Mitochondria

R "Rods" 


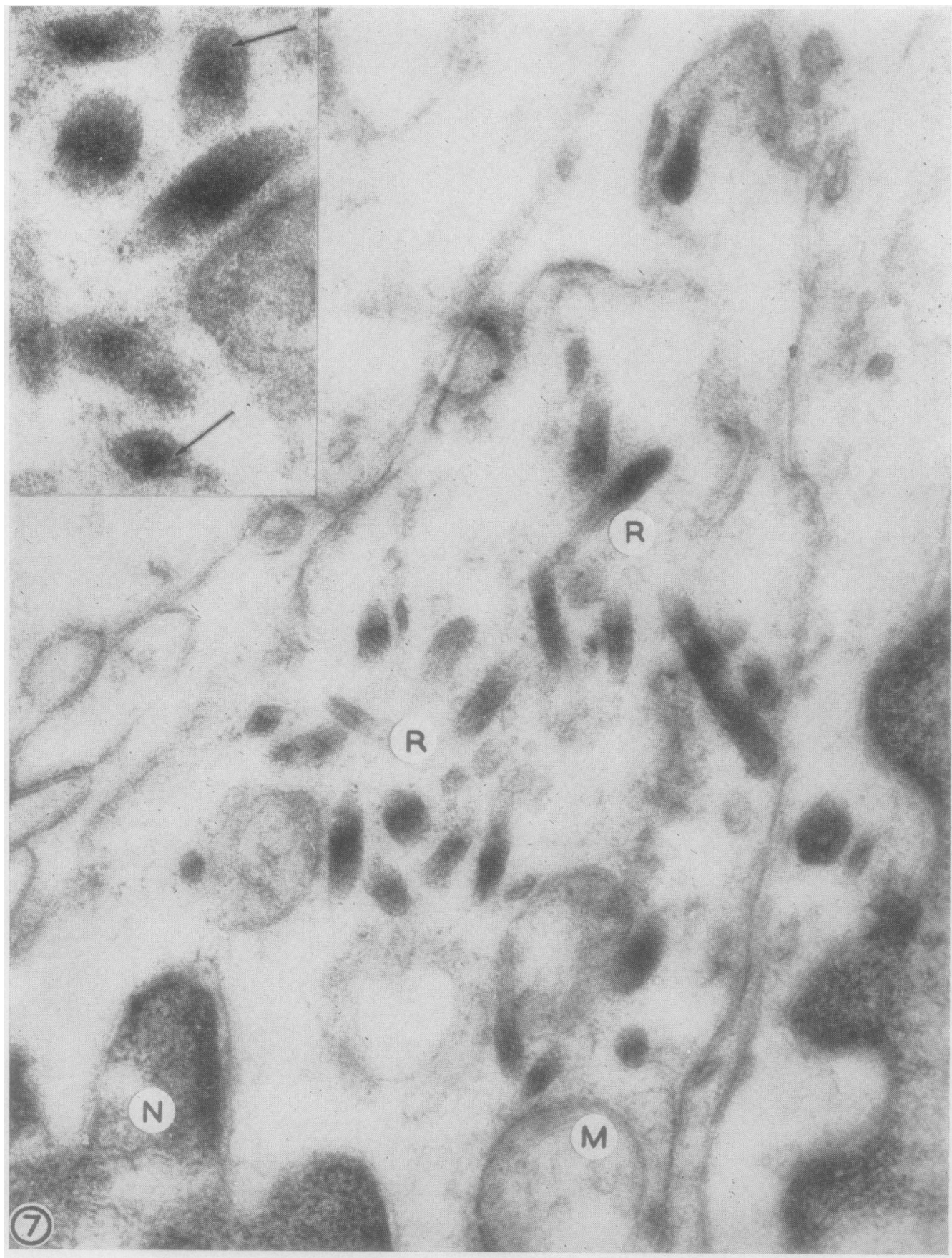

Fig. 7.-Endothelial cell, rheumatoid synovial blood vessel. $\times 50,000$.

$$
\begin{aligned}
\mathbf{M} & \text { Mitochondrion } \\
\mathbf{N} & \text { Nucleus } \\
\mathbf{R} & \text { "Rods" } \\
\text { Inset } & \rightarrow \text { Wall of "rods". } \times 89,000 .
\end{aligned}
$$


(1963) and later Cohen (1964) described the electron microscopic appearance of the intestinal mucosa in Whipple's disease. In this disorder, Cohen (1964) described extracellular rods, the dimensions of which are very similar to those occurring within the cells described in this paper, and Kent and others (1963) demonstrated a few such objects within macrophages. Although arthritis can occur in Whipple's disease (Caughey and Bywaters, 1963), there was no evidence of Whipple's disease in any of our series of patients and in general the intracellular inclusion in macrophages shown by Cohen (1964) bear little resemblance to ours.

More recently, Weibel and Palade (1964) described rod-shaped cytoplasmic components in the endothelial cells of small arteries of the rat and man. They reported that these were found regularly in presumably healthy tissues, but such objects were not seen in any of the controls in this investigation. Further, the "rods" described above differ in appearance from those illustrated by Weibel and Palade and we therefore see no reason to assume that they are the same.

\section{Summary}

Electron microscopic investigations were made on normal and rheumatoid synovia with special reference to the blood vessels. In a proportion of five women with rheumatoid arthritis, hitherto undescribed rod-shaped inclusion bodies were demonstrated. The possible nature of these inclusions is discussed.

Thanks are due to the Golden Kiwi Distribution Committee for the Promotion of Medical Research, the Arthritis and Rheumatism Council of London, and the New Zealand Medical Research Council for financial support. We are indebted to our surgical colleagues for the excised material, and to Miss J. Ledingham and Mr. M. K. Reynolds for technical help.

\section{REFERENCES}

Andersen, H. (1964). Acta anat. (Basel), 58, 90.

Barland, P., Novikoff, A. B., and Hamerman, D. (1962). J. Cell Biol., 14, 207.

,,$---(1964)$. Amer.J. Path., 44, 853.

Caughey, D. E., and Bywaters, E. G. L. (1963). Ann. rheum. Dis., 22, 327.

Caulfield, J. B. (1957). J. biophys. biochem. Cytol., 3, 827.

Cohen, A. S. (1964). J. Ultrastruct. Res., 10, 124.

Coulter, W. H. (1962). Arthr. and Rheum., 5, 70.

Highton, T. C., Caughey, D. E., and Rayns, D. G. (1965). Proc. Univ. Otago med. Sch., 43, 7.

Kent, T. H., Layton, J. M. Clifton, J. A., and Schedl, H. P. (1963). Lab. Invest., 12, 1163.

Kulka, J. P., Bocking, D., Ropes, M. W., and Bauer, W. (1955). A.M.A. Arch. Pathol., 59, 129.

Kurtz, S. M., Davis, T. D., and Ruffin, J. M. (1962). Lab. Invest., 11, 653.

Leader (1965). Brit. med.J., 1, 607.

Middleton, P. J. (1965). Personal communication.

Sabatini, D. D., Bensch, K., and Barrnett, R. J. (1963). J. Cell Biol., 17, 19.

Sharp, J. T. (1964). Arthr. and Rheum., 7, 437.

Weibel, E. R., and Palade, G. E. (1964). J. Cell Biol., 23, 101 .

Une nouvelle inclusion dans la synoviale rhumatismale RÉSUMÉ

On examina au microscope électronique les synoviale normales et rhumatismales, avec attention spéciale auz vaisseaux sanguins. Parmi cinq femmes atteintes d'arth rite rhumatismale on trouva des inclusions en bâtonnet, jusqu'à présent inconnues. On discute la nature de ces inclusions.

Una nueva inclusión en la sinovia reumatoide Sumario

Se examinaron al microscopio electrónico sinovias normales y reumatoides, con referencia especial a los vasos sanguíneos. Entre algunas de las cinco mujeres con artritis reumatoide examinadas se demostraron inclusiones en forma de vara, desconocidos hasta ahora. Se discute la naturaleza de estas inclusiones. 